
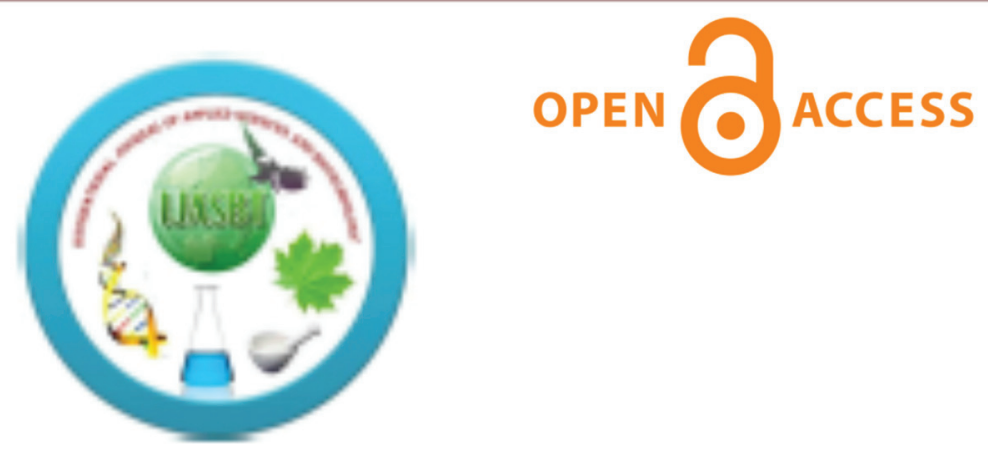

Available online at wwwijasbt.org

International Journal of Applied Sciences and Biotechnology A Rapid Publishing Journal

\begin{tabular}{|c|c|c|}
\hline \multicolumn{2}{|c|}{ APPUED SCIENCES } & BIOTECHNOLOGY \\
\hline $\begin{array}{l}\text { Biochemistry } \\
\text { Molecular biology } \\
\text { Microbiology } \\
\text { Cell biology } \\
\text { Cytology } \\
\text { Genetics } \\
\text { Pathology } \\
\text { Medicinal chemistry } \\
\text { Polymer sciences } \\
\text { Analytical chemistry } \\
\text { Natural chemistry }\end{array}$ & $\begin{array}{l}\text { Immunobiology } \\
\text { Bioinformatics } \\
\text { Novel drug delivery system } \\
\text { Pharmacology } \\
\text { Neurobiology } \\
\text { Bio-physics } \\
\text { Botany } \\
\text { Zoology } \\
\text { Allied science } \\
\text { Earth science }\end{array}$ & $\begin{array}{l}\text { Microbial biotechnology } \\
\text { Medical biotechnology } \\
\text { Industrial biotechnology } \\
\text { Environmental biotechnology } \\
\text { Nanotechnology }\end{array}$ \\
\hline
\end{tabular}

If any queries or feedback, then don't hesitate to mail us at: editor.ijasbt@gmail.com

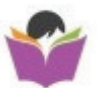




\title{
International Journal of Applied Sciences and Biotechnology
}

ISSN: 2091-2609

\section{EFFECT OF HYDROPRIMING ON FIELD ESTABLISHMENT OF SEEDLINGS OBTAINED FROM PRIMED SEEDS OF BORO RICE cv. BRRI dhan29}

\author{
A. Dey, M.A.R. Sarkar, S.K. Paul ${ }^{*}$ and P.K. Roy \\ Department of Agronomy, Faculty of Agriculture, Bangladesh Agricultural University, \\ Mymensingh-2202, Bangladesh \\ *Corresponding author e-mail: skpaull@gmail.com
}

\begin{abstract}
An experiment was conducted at the Seed Laboratory of the Department of Agronomy, Bangladesh Agricultural University, Mymensingh during the period from January to April 2012 to study the effect of hydropriming on field establishment of seedlings obtained from primed seeds of Boro rice cv. BRRI dhan29. Seeds were soaked in water for 0, 24, 30, 36, 42, 48, 54 and 60 hours. The incubation period was 30 hours at $35^{\circ} \mathrm{C}$ temperature. Seed quality viz. percent germination, mean germination time, vigor index, shoot length, root length, shoot dry weight and root dry weight of rice seedlings were measured. Plant population $\mathrm{m}^{-2}$ was also recorded to understand the field establishment of primed seeds. It was observed that priming treatments had significant effect on germination and other growth parameters of rice seedlings. The highest germination, vigor index, population $\mathrm{m}^{-2}$, length of shoot and root and their weights were found at 15 and 30 DAS. The lowest mean germination time was observed from hydropriming of seeds with 30 hours soaking. On the contrary, no priming treatment showed the lowest germination, vigor index, population $\mathrm{m}^{-2}$, and the highest mean germination time. The study concludes that BRRI dhan29 rice seed could be primed for 30 hours as hydropriming improves germination and field establishment of rice seedlings of Boro rice cv. BRRI dhan29.
\end{abstract}

Key words: Rice, Hydropriming, Germination, Vigor, Seedling establishment.

\section{Introduction}

Rice (Oryza sativa L.) is the most important staple food for a large part of the world's human population, especially in Asia and the West Indies. It is the staple food and extensively cultivated cereal crop in Bangladesh. About $80 \%$ of the total cultivated lands in Bangladesh are used for rice cultivation and its total production is 31.98 million metric tons (BBS, 2011). About $92 \%$ of the world rice is produced and consumed in Asia (Maclean et al., 2002). World rice demand is projected to increase by $25 \%$ from 2001 to 2025 (Maclean et al., 2002). Bangladesh, China, India, Indonesia, Myanmar, the Philippines, Thailand and Vietnam are producing more than $90 \%$ of total Asian rice production (Food Out Look, 2007).

Moisture is the basic requirement for seed germination and essential for enzyme activity. Seedlings that germinate faster and grow rapidly are able to produce sufficient deep root system before the seed bed dries out and harden and these seedlings have enough competitive ability against weeds and seedling diseases. When seeds are sown, they have to absorb water from the soil which takes long time before they germinate. If this time could be reduced by soaking the seed before they are sown, germination happens more quickly resulting in healthier crop. Seeds sown at low moisture condition will not germinate unless sufficient moisture is available. At this situation seed priming can be a simple solution towards stand establishment (Harris et al., 2002). Priming in the semi- arid tropics has been reported to increase emergence, more vigorous plants, better drought tolerance, earlier maturing and higher grain yield (Harris et al., 1999, 2000, 2002).

Seed priming techniques are being used in many parts of the world to reduce the germination time, to get synchronized germination, improve germination rate and better seedling establishment in many field crops viz. rice (Lee and Kim, 1999, 2000; Basra et al., 2003, 2004; Farooq et al., 2004), wheat, maize (Dell Aquilla and Tritoo, 1990; Basra et al., 2002). Hydropriming practically ensured rapid and uniform germination and it had high potential in improving field emergence and ensured early flowering and harvesting under stress condition, especially in dry areas (Singh, 1995 and Shivankar et al., 2003). In many cases, synchronized germination and uniform seedling establishment of this crop is not possible due to insufficient soil moisture. As a result, yield of those crops reduced seriously and farmers fail to achieve their targeted yield. 
So, priming is an effective tool for rapid and uniform seedling emergence. However, methods for priming of rice have not yet been developed in Bangladesh. Hence, the present study was undertaken to investigate the effects of seed priming on germination and seedling establishment of rice to select the best seed soaking time for improving seedling establishment of Boro rice under dry bed direct seeded (DBDS) system; and to see the effects of hydropriming on the establishment potential of seedlings.

\section{Materials and Methods}

The experiment was conducted at the seed testing laboratory of the Department of Agronomy, Bangladesh Agricultural University, Mymensingh during the period from January to April 2012. Seeds of BRRI dhan29 were used as the test material. Treatments of this experiment were $0,24,30,36,42$, 48, 54 and 60 hours soaking followed by 30 hours incubation at $35^{\circ} \mathrm{C}$ temperature. The experiment was laid out in a Completely Randomized Design with three replications. Seed quality parameters viz. germination percentage, mean germination time, vigor index, seedlings shoot and root length were measured at 15 and 30 days after days after sowing(DAS), seedlings shoot and root dry matter at 15 and 30 DAS and population $\mathrm{m}^{-2}$. The daily record of germinated seed was taken 14 days from setting up of the test. The germination test was conducted at $25^{\circ} \mathrm{C}$ temperature in germination room of Seed Laboratory. Daily count of germination of seed was taken on the basis on emergence from the media to calculate data on mean germination time and it was calculated as follows (Goodchild and Walker, 1971): Mean germination time $(\mathrm{MGT})=\frac{\sum t n}{\sum n}$ where, $\mathrm{t}=$ days to germination, $\mathrm{n}=$ number of seedlings germination on day t. Daily count of germination of seed was taken to calculate data on vigor index.

It was calculated by the following formula (Maguire, 1962), vigor index (VI) = $\frac{X_{1}}{N_{1}}+\frac{X_{2}}{N_{2}}+\ldots \ldots \ldots \ldots \ldots . .+\frac{X n}{N n}$ where, $\mathrm{X}_{1}=$ number of seedlings at first count, $\mathrm{N}_{1}=$ number of days at first count, $\mathrm{X}_{2}=$ number of seedlings at second count, $\mathrm{N}_{2}=$ number of days at second count, $X_{n}=$ number of seedlings at final count, $\mathrm{N}_{\mathrm{n}}=$ number of days at final count. Seedling shoot and root lengths were recorded at 15 and 30 DAS.Ten seedlings were carefully uprooted randomly all pots of each treatment with the help of khurpi, and their fresh shoot and root weights were recorded. Then their shoot and root dry weights were recorded after drying in an electric oven at $72^{\circ} \mathrm{C}$ temperature for 48 hours and weighing with an electronic balance. For the measurement of population $\mathrm{m}^{-2}$, seedlings were grown in plastic pots filled with BAU farm soil. Primed seeds were sown in pots in the dry bed direct seeded system (DBDS) system. In one square meter area there were 26 hills whereas three seeds were sown in each hill. Population $\mathrm{m}^{-2}$ was calculated accordingly with the germination percentage of rice seeds.

\section{Results and Discussion}

The hydropriming treatments had significant effect on germination percentage, mean germination time (days), vigor index, shoot length and root length of rice seedlings. The germination of seed for different treatments ranged between $81 \%$ and $95.67 \%$. The highest germination percentage $(95.67 \%)$ was found in 30 hours priming followed by $36,42,48,24,54$ and 60 hours whereas the lowest germination percentage $(81 \%)$ was observed in no priming (Table 1). This result is in agreement with that of Lee et al. (1998) and Basra et al. (2005). Under all conditions, the highest mean germination time was noted in no priming $(9.473$ days). However, the rest of the treatments resulted in lower mean germination time than no priming treatment and minimum mean germination time (8.1 days) was noted in seeds hydroprimed for $30 \mathrm{hrs}$ and it was followed by 36 hours (Table 2). Similar results were also found by Harris et al. (2002) and Lee et al. (1998). The highest vigor index (11.21) was obtained from 30 hours followed by 36 hours priming. The lowest vigor index was obtained in no priming treatments (Table 2). These results were similar to those of Harris et al. (2000), Lee and Kim (2000) and Basra et al. (2003). The highest shoot length at 15 days after sowing (DAS) $(18.32 \mathrm{~cm})$ and at 30 DAS (32.06 $\mathrm{cm})$ was found with seeds primed for 30 hours followed by 48 hours and 36 hours and 36 hours and 48 hours, respectively. On the other hand, the lowest shoot length $(16.71 \mathrm{~cm})$ was found with seed primed for 54 hours (Table 2). Similar results were also found by Tongma et al. (2001) and Farooq et al. (2006). The highest root length at 15 DAS $(6.48 \mathrm{~cm})$ and at 30 DAS $(12.47 \mathrm{~cm})$ was obtained from seeds hydroprimed for 30 hours. The lowest root length at 15 DAS (4.71 $\mathrm{cm})$ was recorded from 60 hours seed hydropriming and at 30 DAS $(10.45 \mathrm{~cm})$ was recorded from 36 hours hydropriming (Table 2). These results are similar to those of Harris et al. (2000), Lee and Kim (2000) and Basra et al. (2003). 
Table 1: Effect of hydropriming on percent germination of BRRI dhan29

\begin{tabular}{|c|c|c|c|c|c|c|c|c|c|c|c|c|c|}
\hline \multirow{3}{*}{$\begin{array}{l}\text { Hydro- } \\
\text { priming } \\
\text { (hrs) }\end{array}$} & \multicolumn{13}{|c|}{ Germination $(\%)$} \\
\hline & \multicolumn{13}{|c|}{ Days after setting for germination } \\
\hline & 3 & 4 & 5 & 6 & 7 & 8 & 9 & 10 & 11 & 12 & 13 & 14 & 15 \\
\hline 0 (control) & $0.333 \mathrm{f}$ & $1.667 \mathrm{f}$ & $12.00 \mathrm{e}$ & $40.00 \mathrm{c}$ & $50.33 c$ & $62.67 \mathrm{~b}$ & $72.67 b$ & $75.67 b$ & $77.00 \mathrm{c}$ & $78.67 \mathrm{~b}$ & $80.67 \mathrm{~b}$ & $81.00 \mathrm{~b}$ & $81.00 \mathrm{~b}$ \\
\hline 24 & $24.33 \mathrm{e}$ & $49.67 \mathrm{e}$ & $73.00 \mathrm{~cd}$ & $82.00 \mathrm{ab}$ & 83.00ab & $85.67 \mathrm{a}$ & $87.67 \mathrm{a}$ & $88.67 \mathrm{a}$ & $90.33 \mathrm{ab}$ & $90.67 \mathrm{a}$ & $91.67 \mathrm{a}$ & $91.67 \mathrm{a}$ & $91.67 \mathrm{a}$ \\
\hline 30 & $59.33 \mathrm{a}$ & $82.33 \mathrm{a}$ & $86.00 \mathrm{a}$ & $88.33 \mathrm{a}$ & $89.33 a$ & $90.33 a$ & $92.67 \mathrm{a}$ & $93.00 \mathrm{a}$ & $94.00 \mathrm{a}$ & $94.67 \mathrm{a}$ & $95.67 \mathrm{a}$ & $95.67 \mathrm{a}$ & $95.67 \mathrm{a}$ \\
\hline 36 & $46.33 b$ & $74.33 b$ & $83.67 \mathrm{ab}$ & $86.00 \mathrm{ab}$ & $87.67 \mathrm{ab}$ & $89.00 \mathrm{a}$ & $90.67 \mathrm{a}$ & $91.33 \mathrm{a}$ & $92.00 \mathrm{ab}$ & $92.67 \mathrm{a}$ & $93.67 \mathrm{a}$ & $94.33 \mathrm{a}$ & $94.33 \mathrm{a}$ \\
\hline 42 & $34.33 d$ & $51.67 \mathrm{e}$ & $68.00 \mathrm{~d}$ & $74.00 \mathrm{~b}$ & $77.67 \mathrm{~b}$ & $80.33 a$ & $85.67 \mathrm{a}$ & $88.00 \mathrm{a}$ & $89.67 \mathrm{ab}$ & $91.33 \mathrm{a}$ & $92.00 \mathrm{a}$ & $93.33 \mathrm{a}$ & $93.33 \mathrm{a}$ \\
\hline 48 & $40.33 c$ & $67.33 \mathrm{c}$ & $84.33 a$ & $84.33 \mathrm{ab}$ & $84.00 \mathrm{ab}$ & $86.67 \mathrm{a}$ & $88.00 \mathrm{a}$ & $88.33 a$ & $88.67 \mathrm{ab}$ & $89.00 \mathrm{a}$ & $90.33 a$ & $91.67 \mathrm{a}$ & $91.67 \mathrm{a}$ \\
\hline 54 & $42.33 b c$ & $67.00 \mathrm{~cd}$ & $77.33 \mathrm{bc}$ & $82.67 \mathrm{ab}$ & $85.67 \mathrm{ab}$ & $87.67 \mathrm{a}$ & $88.33 a$ & $90.00 \mathrm{a}$ & $91.00 \mathrm{ab}$ & $91.33 \mathrm{a}$ & $91.67 \mathrm{a}$ & $91.67 \mathrm{a}$ & $91.67 \mathrm{a}$ \\
\hline 60 & $34.33 d$ & $61.33 d$ & $82.67 \mathrm{ab}$ & $83.67 \mathrm{ab}$ & $85.00 \mathrm{ab}$ & $85.67 \mathrm{a}$ & $87.00 \mathrm{a}$ & $87.33 a$ & $88.00 \mathrm{~b}$ & $89.67 \mathrm{a}$ & $90.00 \mathrm{a}$ & $90.33 a$ & $91.00 \mathrm{a}$ \\
\hline $\begin{array}{l}\text { Level of } \\
\text { sign. }\end{array}$ & $* *$ & $* *$ & $* *$ & $* *$ & $* *$ & $* *$ & $* *$ & $* *$ & *** & $* *$ & $* *$ & $* *$ & $*$ \\
\hline $\mathrm{CV}(\%)$ & 7.49 & 5.71 & 4.98 & 8.77 & 6.73 & 6.30 & 4.93 & 4.38 & 3.31 & 3.27 & 3.34 & 3.86 & 4.77 \\
\hline
\end{tabular}

The figures in a column having the same letter do not differ significantly whereas figures with dissimilar letter differ significantly as per DMRT.

** $=$ Significant at $1 \%$ level of probability

Table 2: Effect of hydropriming on shoot length, root length, shoot weight, root weight, population $\mathrm{m}^{-2}$, mean germination time, and vigor index of BRRI dhan 29

\begin{tabular}{|c|c|c|c|c|c|c|c|c|c|c|c|}
\hline \multirow[t]{2}{*}{ Treatment } & \multicolumn{4}{|c|}{ At 15 days } & \multicolumn{4}{|c|}{ At 30 days } & \multirow{2}{*}{$\begin{array}{c}\text { Population } \\
\mathrm{m}^{-2} \\
\text { (no.) }\end{array}$} & \multirow{2}{*}{$\begin{array}{c}\text { Mean germinatior } \\
\text { time } \\
\text { (days) }\end{array}$} & \multirow{2}{*}{$\begin{array}{l}\text { Vigor } \\
\text { index }\end{array}$} \\
\hline & $\begin{array}{l}\text { Shoot } \\
\text { length } \\
(\mathrm{cm})\end{array}$ & $\begin{array}{l}\text { Root } \\
\text { length } \\
(\mathrm{cm})\end{array}$ & $\begin{array}{c}\text { Root } \\
\text { dry } \\
\text { weight } \\
\text { (g) }\end{array}$ & $\begin{array}{l}\text { Shoot } \\
\text { dry } \\
\text { weight } \\
\text { (g) }\end{array}$ & $\begin{array}{l}\text { Shoot } \\
\text { length } \\
(\mathrm{cm})\end{array}$ & $\begin{array}{l}\text { Root } \\
\text { length } \\
(\mathrm{cm})\end{array}$ & $\begin{array}{l}\text { Shoot dry } \\
\text { weight } \\
(\mathrm{g})\end{array}$ & $\begin{array}{l}\text { Root dry } \\
\text { weight } \\
(\mathrm{g})\end{array}$ & & & \\
\hline $0 \mathrm{hr}$ (control) & $17.97 \mathrm{a}$ & $5.85 \mathrm{~b}$ & 0.007 & 0.036 & $24.01 \mathrm{~d}$ & $11.69 \mathrm{~b}$ & $0.763 \mathrm{~d}$ & $0.390 \mathrm{abc}$ & $63.18 b$ & $9.473 a$ & $6.203 \mathrm{c}$ \\
\hline $24 \mathrm{hr}$ & $17.92 \mathrm{a}$ & $5.220 \mathrm{~cd}$ & 0.010 & 0.039 & $26.98 \mathrm{bcd}$ & $10.65 d$ & $0.907 \mathrm{bcd}$ & $0.3667 \mathrm{abc}$ & $71.50 \mathrm{a}$ & 8.677abcd & $9.613 b$ \\
\hline $30 \mathrm{hr}$ & $18.32 \mathrm{a}$ & $6.480 \mathrm{a}$ & 0.013 & 0.043 & $32.06 \mathrm{a}$ & $12.47 \mathrm{a}$ & $1.173 \mathrm{a}$ & $0.4267 \mathrm{a}$ & $74.62 \mathrm{a}$ & $8.100 \mathrm{~d}$ & $11.21 \mathrm{a}$ \\
\hline $36 \mathrm{hr}$ & $18.25 \mathrm{a}$ & $5.573 b c$ & 0.009 & 0.033 & $30.08 \mathrm{ab}$ & $10.45 d$ & $1.097 \mathrm{ab}$ & $0.4067 \mathrm{abc}$ & $73.58 \mathrm{a}$ & $8.557 \mathrm{bcd}$ & $10.42 \mathrm{ab}$ \\
\hline $42 \mathrm{hr}$ & $17.88 \mathrm{a}$ & $5.630 \mathrm{bc}$ & 0.005 & 0.037 & $25.51 \mathrm{~cd}$ & $11.53 \mathrm{~b}$ & $0.857 \mathrm{~cd}$ & $0.4167 \mathrm{ab}$ & $72.80 \mathrm{a}$ & $9.027 \mathrm{abc}$ & $9.180 \mathrm{~b}$ \\
\hline $48 \mathrm{hr}$ & $18.29 \mathrm{a}$ & $4.95 \mathrm{de}$ & 0.007 & 0.037 & $29.70 \mathrm{ab}$ & $11.05 \mathrm{c}$ & $1.017 \mathrm{abc}$ & $0.4233 \mathrm{ab}$ & $71.48 \mathrm{a}$ & $8.923 \mathrm{abc}$ & $9.653 b$ \\
\hline $54 \mathrm{hr}$ & $16.71 \mathrm{~b}$ & $5.79 \mathrm{~b}$ & 0.009 & 0.035 & $29.05 a b c$ & $10.62 d$ & $0.860 \mathrm{~cd}$ & $0.3633 b c$ & $71.50 \mathrm{a}$ & $8.253 \mathrm{~cd}$ & $10.38 \mathrm{ab}$ \\
\hline $60 \mathrm{hr}$ & $17.87 \mathrm{a}$ & $4.710 \mathrm{e}$ & 0.008 & 0.038 & $26.73 \mathrm{bcd}$ & $10.71 d$ & $0.940 \mathrm{bcd}$ & $0.3500 \mathrm{c}$ & $70.98 \mathrm{a}$ & $9.173 \mathrm{ab}$ & $9.287 \mathrm{~b}$ \\
\hline $\begin{array}{l}\text { Level of } \\
\text { significance }\end{array}$ & $* *$ & $* *$ & NS & NS & ** & $* *$ & ** & ** & ** & $* *$ & *** \\
\hline $\mathrm{CV}(\%)$ & 2.57 & 4.62 & - & - & 6.80 & 1.48 & 11.44 & 6.25 & 4.50 & 4.72 & 7.15 \\
\hline
\end{tabular}

The figures in a column having the same letter and no letter do not differ significantly whereas figures with dissimilar letter differ significantly as per DMRT.

NS $=$ Not significantly different at $\mathrm{p} \leq 0.05$

$* *=$ Significant at $1 \%$ level of probability

The shoot and root dry weights of rice seedlings did not differ significantly due to seed priming treatments. However, apparently, the highest shoot dry matter accumulation at 15 DAS (0.043g) and at 30 DAS $(1.173 \mathrm{~g})$ per seedling was measured in 30 hours followed by 24 hours of hydro-priming. The lowest shoot dry matter accumulation at 15 DAS (0.033 g) and at 30 DAS $(0.763 \mathrm{~g})$ per seedling were found in 36 hours and no priming treatments, respectively (Table 2). Apparently, the highest root dry weight at 15 DAS (0.013) was found with seed primed for 30 hours and the lowest root dry weight at 15 DAS $(0.005 \mathrm{~g})$ was found with 42 hours seed priming. The highest root dry weight at 30 DAS $(0.4267 \mathrm{~g})$ was found with seed primed in 30 hours and the lowest root dry weight at 30 DAS $(0.3500 \mathrm{~g})$ value was found in 60 hours hydropriming (Table 2). Similar results were also found by Tongma et al. (2001) and Farooq et al. (2006).

Hydropriming treatments had significant effect on seedling population $\mathrm{m}^{-2}$. The highest population $\mathrm{m}^{-2}$ of rice seedlings (74.62) was obtained in 30 hours priming whereas the lowest population $\mathrm{m}^{-2}$ of rice seedlings (63.18) was found with no priming treatments.

In conclusion, the Boro rice (cv. BRRI dhan29) seed could be hydroprimed for 30 hours followed by incubation at $35^{\circ} \mathrm{C}$ temperature for 30 hours to enhance germination percentage and field establishment of seedlings.

\section{Acknowledgement}

The financial assistance of Ministry of Science and Technology, Govt. of the People's Republic of Bangladesh, to conduct the research project is thankfully acknowledged.

\section{References}

Basra SMA, Farooq M and Khaliq A (2003). Comparative study of pre-sowing seed enhancement treatments in indica rice (Oryza sativa L.). Pak. J. Life Soci. Sci. 1: 5-9.

Basra SMA, Farooq M and Tabassum R (2005). Physiological and biochemical aspects of seed vigor 
enhancement treatments in fine rice (Oryza sativa L.). Seed Sci. Technol. 33: 623-628.

Basra SMA, Farooq M, Hafeez K and Ahmad N (2004). Osmohardening: A new technique for rice seed invigoration. Rice Res. Notes. 29: 80-81.

Basra SMA, Zia MN, Mehmood T, Afjal I and Khaliq A (2002). Comparison of different invigoration techniques in wheat (Triticum aestivum L.) seeds. Pak. J. Arid Agric. 5: 11-16.

BBS (Bangladesh Bureau of Statistics) (2011). Statistical Yearbook of Bangladesh. Bangladesh Bur. Stat., Stat. Div., Minis. Plann. Govt. People's Repub. Bangladesh, Dhaka. P. 123-127.

Dell Aquilla A and Tritto V (1990). Ageing and osmotic priming in wheat seeds: Effects upon certain components of seed quality. Ann. Bot. 65: 21- 26.

Farooq M, Basra SMA and Rehman HU (2006). Seed priming enhances emergence, yield, and quality of direct-seeded rice. Inter. Rice Res. Notes. 31 (2): 4244.

Farooq M, Basra SMA, Hafeez K and Warriach EA (2004). The influence of high and low temperature treatments on the seed germination and seedling vigor of coarse and fine rice. Int. Rice Res. Notes. 29: 69-71.

Food Out Look. 2007. Global Market Analysis. Food and Agriculture Organization (FAO). Rome, Italy. November 2007. P. 67- 68.

Goodchild NA and Walker MG (1971). Measurement of germination. Ann. Bot. 35: 615- 621.

Harris D, Johi A, Khan PA, Gothkar P and Sodhi PS (1999). On-farm priming in semi-arid agriculture: Development and evaluation in maize and chickpea in India using participatory methods. Exp. Agric. 35: 1529.

Harris D, Rashid A, Hollington PA, Jasi L and Riches C
(2002). Prospect of improving maize yield with onfarm seed priming. In: Rajbhandari N P, Ransom J K, Adhikari K, Palmer A F E (Eds.). Sustainable maize production system for Nepal. Kathmandu: NARC and CIMMYT. P. 180-185.

Harris D, Tripathi RS and Joshi A (2000). On farm seed priming improve crop establishment and yield in dry direct seeded rice. Paper presented at the Workshop on Dry-Seeded Rice Technology, Bangkok, Thailand. Refine a key technology. Agric. Syst. 69: 151-164.

Lee SS and Kim JH (2000). Total sugars, $\alpha$-amylase activity and germination after priming of normal and aged rice seeds. Kor J. Crop Sci. 43:157-160.

Lee SS and Kim JH (1999). Morphological change, sugar content and $\alpha$-amylase activity of rice seeds under various priming conditions. Kor J. Crop Sci. 44:138142.

Maclean JL, Dawe DC, Hardly B and Hettel GP (2002). Rice Almanace Los Banos (Philippines): Inter. Rice Res. Inst., Bouke (Coted. Lovire): West Africa Rice Dev. Cali (Colombia): Inter. Center Trop. Agric., Rome (Italy): Food Agric. Org. P. 253.

Maguire ID (1962). Speed of germination-aid in selection and evaluation for seedling emergence and vigor. Crop Sci. 2: 176 - 177.

Shivankar RS, Deore DB and Zode NG (2003). Effect of presowing seed treatment on establishment and seed yield sunflower. J. Oilseed Res. 20: 299 - 300.

Singh BG (1995). Effect of hydration dehydration seed treatments on vigour and yield of sunflower. Indian $J$. Plant. Physiol. 38: 66 - 68.

Tongma S, Kobayashi K and Usui K (2001). Allelopathic activity of Mexican sunflower [Tithonia diversifolia (Hemsl.) A. Gray] in soil under natural field conditions and different moisture conditions. Weed Biol. Manageme. 